\title{
Testing pollution haven and pollution halo hypotheses for Turkey: a new perspective
}

\author{
Mehmet Mert ${ }^{1} \cdot$ Abdullah Emre Caglar ${ }^{1}$ \\ Received: 4 March 2020 / Accepted: 26 May 2020 / Published online: 10 June 2020 \\ (C) Springer-Verlag GmbH Germany, part of Springer Nature 2020
}

\begin{abstract}
In this study, we analyzed the asymmetric short- and long-run causal links between foreign direct investments and emissions in Turkey over the time period 1974-2018. Using hidden co-integration techniques, we defined and tested the asymmetric pollution haven and asymmetric pollution halo hypotheses. To evaluate the long-run asymmetric causal relationship, we estimated both the crouching error correction model and vector error correction model. We performed a stepwise regression model to estimate the crouching error correction model. The empirical results confirmed an asymmetric causal relationship between positive shocks of foreign direct investments and positive movements in emissions in the short run as well as an asymmetric causal link between negative and positive shocks of foreign direct investments and positive emissions in the long run. Furthermore, the results showed that increases in foreign direct investments led to a decrease in the rate of emission growth in both the short and long run. This finding supports the validity of the asymmetric pollution halo hypothesis in Turkey's case. Policymakers should strengthen their environmental protection laws to protect the quality of their environments as well as implement policies that encourage the use of clean technology and tax incentives that increase foreign direct investment inflows.
\end{abstract}

Keywords Asymmetric pollution haven hypothesis · Asymmetric pollution halo hypothesis · Short- and long-run asymmetric causality $\cdot$ Hidden co-integration $\cdot$ Crouching error correction model

\section{Introduction}

Environmental degradation has undoubtedly proven to be one of the most important problems humanity must face in the twenty-first century. Anthropogenic greenhouse gases represent an important source of environmental degradation. Since the beginning of the Industrial Revolution in the eighteenth

Highlights • FDI inflows-emissions nexus is analyzed using a hidden cointegration approach.

- To estimate the crouching error correction model, stepwise regression was performed.

- We found evidence in favor of the asymmetric pollution halo hypothesis.

- We defined long-run asymmetric causality

Responsible Editor: Philippe Garrigues

Abdullah Emre Caglar

aecaglar@akdeniz.edu.tr; emreacaglar@gmail.com

Mehmet Mert

mmert@akdeniz.edu.tr

1 Akdeniz University, Antalya, Turkey century, fossil fuel usage has increased $\mathrm{CO}_{2}$ levels from about 280 parts per million ( $\mathrm{ppm}$ ) in pre-industrial times to about $387 \mathrm{ppm}$ at the beginning of this century and further to $400 \mathrm{ppm}$ now, according to the National Oceanic and Atmospheric Administration (NOAA) Annual Greenhouse Gas Index (Boden et al. 2009; Butler and Montzka 2019). Carbon emissions $\left(\mathrm{CO}_{2}\right)$ are known to represent the most significant contributor to recent climate change (Cai et al. 2018). Global energy-related carbon emissions increased by $1.7 \%$ in 2018, the highest growth rate since 2013 (IEA 2018). Why do countries not reduce $\mathrm{CO}_{2}$ emissions despite international agreements to do so such as the Kyoto Protocol and the Paris Agreement? In other words, why have $\mathrm{CO}_{2}$ emissions increased recently? According to a study by the Center for Global Development, developing countries account for $63 \%$ of the current $\mathrm{CO}_{2}$ emissions (Center for Global Development 2015). In addition, the Clean Development Mechanism established under the Kyoto Protocol does not require developing countries to curtail their emissions that result from trade activities, while industrialized countries must reduce their emissions to a certain level to comply with the Protocol. This effect is confirmed in the United Nations Conference 
on Trade and Development (UNCTAD) 2019 report, which stated that "annual carbon emissions have accelerated in developing countries and have stabilized in developed countries" (UNCTAD 2019).

The Kyoto Protocol drew attention to trade activities in developing countries, which view foreign direct investment (FDI) as an important strategy for economic growth. FDI inflows to the developing countries have increased, especially in the last three decades, due to increased globalization and the free movement of capital. Developing countries cannot allocate sufficient resources to investments that will contribute to economic development to achieve their growth targets. Therefore, FDI can provide some of the resources required. FDI can assist in a country's development through technology transfer, improved productivity, new management skills, and infrastructure developments. Although FDI contributes to economic growth in the host country, it also raises controversy about environmental quality. The environmental economics literature approaches this question through two opposing hypotheses. The first, the pollution haven hypothesis, states that pollution-intensive production activities are directed from developed countries to those with more lax environmental regulations through FDI. Thus, developed economies reduce the costs of adapting to environmental regulations and benefit from a cheap labor force. The other hypothesis, known as the pollution halo hypothesis, claims that companies from the investing developed countries contribute to the host country's reduction of emissions because their production structure relies on green technology, unlike the host country's existing production.

Since the second half of the twentieth century, developed countries have imported many products from developing countries and in this way exported their $\mathrm{CO}_{2}$ emissions to the developing countries (Peters and Hertwich 2008). Developed economies ultimately seek to keep the global temperature rise below $2{ }^{\circ} \mathrm{C}$. Thus, the developed countries transferred $16 \mathrm{Gt} \mathrm{CO}_{2}$ emissions to the developing countries between 1990 and 2008 through international trade (Peters et al. 2011). In Turkey, a developing country, both $\mathrm{CO}_{2}$ emissions and FDI inflows increased during the same period (World Bank 2019). The EY Attractiveness Survey Europe 2019 named Turkey Europe's 7th most popular international investment destination in 2018. FDI in Turkey increased 209 billion dollars, more than tenfold the original amount, between the years 2003 and 2018 (Central Bank of the Republic of Turkey 2019). BP (2019) confirms that Turkey emitted 209.9 million tons of $\mathrm{CO}_{2}$ in 2003, which had increased to 389.9 million tons by 2018. Turkey seems to be quite far from their emission targets in both the Kyoto Protocol and the Paris Agreement. Turkey's capability to reduce their $\mathrm{CO}_{2}$ emissions will also play an important role in their EU membership process. Thus, deeply investigating the effect of FDI on $\mathrm{CO}_{2}$ emissions is essential for Turkish policymakers. Therefore, we believe that use of advanced econometric techniques to investigate the effect of FDI on $\mathrm{CO}_{2}$ emissions in Turkey not only assists in guiding Turkey's environmental policy but also provides an important contribution to the environmental economics literature as a whole.

This study examines the asymmetric impact of FDI on Turkey's $\mathrm{CO}_{2}$ emissions between the years 1974 and 2018. In this context, this study aims mainly to asymmetrically analyze the relationship between FDI and $\mathrm{CO}_{2}$ emissions in the short as well as long run, as opposed to the existing literature which examines these links symmetrically, as both FDI and $\mathrm{CO}_{2}$ can react differently to random shocks. For example, a negative shock in a host country may cause some companies to believe that the situation is temporary, deciding to maintain their position and continue their investments in that country. However, some companies do not want to take the risks associated with the negative situation and may withdraw their investments. Similarly, emissions can increase or decrease due to shocks. For instance, while some countries choose to restrict emissions through protective policies, others avoid serious measures due to economic losses from negative shocks. Therefore, analyzing each of these variables' disparate reactions to positive versus negative shocks strengthens the validity of the research. In this context, our study distinguishes the asymmetric effects of shocks on the short- and long-term relationships between the variables.

To the best of our knowledge, the pollution halo/haven hypotheses have only been tested symmetrically. However, negative and the positive shocks can affect pollution differently. With this in mind, we obtained the negative and the positive cumulative shocks of FDI and $\mathrm{CO}_{2}$ emissions for Turkey. After analyzing short-run asymmetric causality by using the negative and positive cumulative shocks, we performed hidden co-integration techniques drawn from Granger and Yoon (2002), and Hatemi-J and Irandost (2012) to test the asymmetric pollution halo and haven hypotheses in Turkey. The hidden co-integration methodology allows researchers to evaluate relationships between the positive and negative cumulative shocks of the series. The hidden co-integration procedure uses the cumulative shocks of the variables to allow estimation of long-run asymmetric relationships between the series. By estimating the crouching error correction model (CECM) after performing Granger and Yoon's (2002) hidden co-integration test and the vector error correction model (VECM) after performing Hatemi-J and Irandost(2012) hidden cointegration test, we estimated the short-run relationships between the cumulative positive and negative shocks of the variables. Furthermore, we defined the long-run asymmetric causality between the variables based on the error correction models.

This study contributes to the literature in the following ways: firstly, by asymmetrically testing both the pollution halo and haven hypotheses. Secondly, it investigates the 
long-run asymmetric causality through the estimation of the error correction model. Finally, it proposes stepwise regression to estimate the CECM drawn from Mert and Caglar's (2019) study. An examination of the literature reveals that no more than four lags are usually incorporated in the crouching error correction model as it is too computationally intensive to add more (see Honarvar 2009; Alom and Ritson 2012; Alexakis et al. 2013; Koutroulis et al. 2016). However, the crouching error correction model may possess more than 4 lags. This discrepancy may lead to omitted variable bias in the studies. To correct for such bias, we thus suggest stepwise regression to select the lags in the crouching error correction model initially proposed by Mert and Caglar (2019), thus providing a methodological contribution to the literature. In this way, this study provides a new perspective in the ongoing debate about the FDI-emission relationship.

The next section of the study presents a review of the current literature on the pollution haven and pollution halo hypotheses. "Data and methods" describes the data and econometric methodology of the study. "Findings" presents empirical findings, and "Discussion" concludes the study.

\section{Literature review}

The relationship between environmental degradation and FDI inflows has become a popular topic of discussion in environmental economics. The current literature presents two opposing hypotheses examining the impact of FDI on environmental degradation. The first, the well-known pollution haven hypothesis, posits that global companies outsource pollutionintensive industries to countries with cheap labor and lax environmental regulations. These countries, which do not possess the resources necessary for economic development, instead depend on external investments. They rely on legislative incentives to encourage FDI. This hypothesis is partially explained by Grossman and Krueger's (1991) scale effect, which postulates that countries need more natural resources and inputs in the first stage of economic growth. Thus, FDI-led growth in the first stage of economic development should lead to more environmental pollution. Zhang and Zhou (2016) found that FDI inflows could enhance the host country's economic activities, which triggers an increase in environmental pollution if the lax regulations of the host countries are not changed. On the contrary, the pollution halo hypothesis posits that multinational companies transfer new production processes, management skills, and greener technologies to the host country by complying with the international environmental standard framework, thus contributing to a reduction in carbon emissions of the host country.

An examination of the current literature investigating the effect of FDI on environmental degradation reveals the importance of country selection in the studies. While some studies consider individual countries, others analyze country groups. Shahbaz's (2015) work serves as a pioneer for the literature on the FDI-emission links; as previous work had proven that this relationship changes by country groups (i.e., low, middle, and upper countries, etc.), his study demonstrated the pollution haven hypothesis is more strongly supported in low- and middle-income countries, while the pollution halo hypothesis appears more valid in high-income countries. Table 1 presents a summary of several studies that investigated whether FDI causes environmental pollution in the host country through various econometric methods.

Contradictory views frequently occur in the literature, especially in studies that focus on FDI and environmental pollution. While some studies support the pollution haven hypothesis (Akbostanc1 et al. 2007; Kivyiro and Arminen (2014); Seker et al. 2015; Solarin et al. 2017; Gorus and Aslan 2019; Caglar 2020), others find stronger evidence for the pollution halo hypothesis (Hao and Liu 2015; Mert and Boluk 2016; Rafindadi et al. 2018; Balsalobre-Lorente et al. 2019). In addition, some studies (Lee 2013; Shaari et al. 2014) demonstrate that the neutrality hypothesis is more appropriate for explaining the relationship between these two variables. Studies examining the FDIemission link in Turkey employ both the standard ARDL and the Johansen and Maki structural breaks co-integration tests. Table 1 shows that the pollution haven hypothesis is more strongly supported in all the studies focusing on Turkey except in Ozturk and $\mathrm{Oz}$ (2016). In general, criteria such as country selection, data length, and econometric method play a key role in the difference in results. The FDI-emission literature relies most frequently on co-integration and causality analysis such as ARDL cointegration and Granger causality. Our study examines the short- and long-term asymmetric causality for the $\mathrm{FDI}-\mathrm{CO}_{2}$ emission relationship in Turkey. We use the Hatemi-J (2012) asymmetric causality test for short-term analysis, while we employ both the Granger and Yoon (2002) and Hatemi-J and Irandost (2012) hidden co-integration approaches, which, to the best of our knowledge, have not yet been used in the relevant literature, for long-term causality.

\section{Data and methods}

We obtained the 1974-2018 time series of carbon dioxide $\left(\mathrm{CO}_{2}\right)$ emissions (metric tons per capita) from BP statistics and the net foreign direct investment (current US\$) series (FDI) from the World Bank online database over the same time period. We used different data sources for each series since the series FDI was available on World Bank database until 2018, but its emission series only ran until 2014. We used the natural logarithms of both series for analysis. To obtain the natural logarithm of the FDI series, we added a constant value to the series so that all its values were positive. 
Table 1 Summary of FDI-emissions nexus empirical studies

\begin{tabular}{|c|c|c|c|c|}
\hline Reference & Location & Period & Methodology & Result \\
\hline \multicolumn{5}{|c|}{ Category A: time series papers } \\
\hline $\begin{array}{l}\text { Solarin et al. } \\
(2017)\end{array}$ & Ghana & $1980-2012$ & ARDL & Pollution haven \\
\hline $\begin{array}{l}\text { Rana and Sharma } \\
\text { (2019) }\end{array}$ & India & $1982-2013$ & $\begin{array}{l}\text { ARDL and dynamic multivariate } \\
\text { Toda-Yamamoto (TY) approach }\end{array}$ & Pollution haven \\
\hline Sun et al. (2017) & China & $1980-2012$ & ARDL & Pollution haven \\
\hline $\begin{array}{l}\text { Tang and Tan } \\
(2015)\end{array}$ & Vietnam & 1976-2009 & $\begin{array}{l}\text { Johansen co-integration approach and } \\
\text { Granger causality }\end{array}$ & Pollution halo \\
\hline $\begin{array}{l}\text { Shahbaz et al. } \\
\text { (2018) }\end{array}$ & France & 1955-2016 & Bootstrap ARDL & Pollution haven \\
\hline Lau et al. (2014) & Malaysia & $1970-2008$ & ARDL and Granger causality & Pollution haven \\
\hline $\begin{array}{l}\text { Bello and Adeniyi } \\
\text { (2010) }\end{array}$ & Nigeria & $1970-2006$ & ARDL & Pollution haven \\
\hline $\begin{array}{l}\text { Merican et al. } \\
\text { (2007) }\end{array}$ & $\begin{array}{l}\text { ASEAN } 5 \\
\text { countries }\end{array}$ & $1970-2001$ & ARDL & $\begin{array}{l}\text { Malaysia, Thailand, and Philippines for } \\
\text { pollution haven; Indonesia for pollution } \\
\text { halo; and Singapore for neutrality }\end{array}$ \\
\hline \multicolumn{5}{|c|}{ Category B: panel data papers } \\
\hline Lee $(2013)$ & G20 countries & $1971-2009$ & Panel fixed effect & Pollution haven \\
\hline $\begin{array}{l}\text { Shahbaz et al. } \\
\text { (2015) }\end{array}$ & $\begin{array}{l}\text { Low-, middle-, } \\
\text { and } \\
\text { high-income } \\
\text { countries }\end{array}$ & 1975-2012 & $\begin{array}{l}\text { Co-integration (i.e., Pedroni, Fisher), } \\
\text { FMOLS estimator, and } \\
\text { Dumitrescu-Hurlin causality }\end{array}$ & $\begin{array}{l}\text { Pollution haven for low- and middle-income } \\
\text { countries } \\
\text { Pollution halo for high-income countries }\end{array}$ \\
\hline Baek (2016) & $\begin{array}{l}\text { ASEAN } 5 \\
\text { countries }\end{array}$ & $1981-2010$ & Pedroni for co-integration and panel ARDL & Pollution haven \\
\hline $\begin{array}{l}\text { Bakirtas and Cetin } \\
\text { (2017) }\end{array}$ & $\begin{array}{l}\text { MIKTA } \\
\text { countries }\end{array}$ & $1982-2011$ & Panel VAR & Pollution haven \\
\hline $\begin{array}{l}\text { Al-Mulali and } \\
\text { Ozturk (2015) }\end{array}$ & $\begin{array}{l}\text { MENA } \\
\text { countries }\end{array}$ & $1996-2012$ & $\begin{array}{l}\text { Pedroni for co-integration, FMOLS for } \\
\text { estimator, and VECM Granger causality }\end{array}$ & Pollution haven \\
\hline $\begin{array}{l}\text { Mert and Boluk } \\
\text { (2016) }\end{array}$ & Kyoto countries & Unbalanced & Panel ARDL & Pollution halo \\
\hline Mert et al. (2019) & $\begin{array}{l}\text { Different } \\
\text { European } \\
\text { country } \\
\text { groups }\end{array}$ & Unbalanced & Panel ARDL & Pollution haven \\
\hline $\begin{array}{l}\text { Destek and } \\
\text { Okumus (2019) }\end{array}$ & $\begin{array}{l}10 \text { newly } \\
\text { industrialized } \\
\text { countries }\end{array}$ & $1982-2013$ & $\begin{array}{l}\text { Error correction-based co-integration ap- } \\
\text { proach and CCE estimator }\end{array}$ & NA \\
\hline $\begin{array}{l}\text { Balsalobre-Lorente } \\
\text { et al. (2019) }\end{array}$ & Mint countries & $1990-2013$ & $\begin{array}{l}\text { Pedroni, Kao, and Fisher for co-integration; } \\
\text { FMOLS and DOLS for estimator; } \\
\text { Dumitrescu-Hurlin causality }\end{array}$ & Pollution halo \\
\hline $\begin{array}{l}\text { Albulescu et al. } \\
\text { (2019) }\end{array}$ & $\begin{array}{l}\text { 4 Latin } \\
\text { American } \\
\text { countries }\end{array}$ & $1980-2010$ & Panel quantile regression & NA \\
\hline \multicolumn{5}{|c|}{ Category C: papers based on Turkey } \\
\hline Seker et al. (2015) & Turkey & $1974-2010$ & $\begin{array}{l}\text { ARDL, Hatemi-J co-integration, and } \\
\text { Granger causality }\end{array}$ & Pollution haven \\
\hline $\begin{array}{l}\text { Terzi and Pata } \\
\text { (2019) }\end{array}$ & Turkey & $1974-2011$ & $\begin{array}{l}\text { Toda-Yamamoto-augmented Granger } \\
\text { causality }\end{array}$ & Pollution haven \\
\hline $\begin{array}{l}\text { Kocak and } \\
\text { Sarkgunesi } \\
(2018)\end{array}$ & Turkey & 1974-2013 & $\begin{array}{l}\text { Maki for co-integration, DOLS for } \\
\text { estimator, and Hacker and Hatemi } \\
\text { bootstrap causality }\end{array}$ & Pollution haven \\
\hline $\begin{array}{l}\text { Kilicarslan and } \\
\text { Dumrul (2017) }\end{array}$ & Turkey & $1974-2013$ & Johansen co-integration & Pollution haven \\
\hline $\begin{array}{l}\text { Ozturk and } \mathrm{Oz} \\
\text { (2016) }\end{array}$ & Turkey & $1974-2011$ & $\begin{array}{l}\text { Maki for co-integration, DOLS for } \\
\text { estimator, and Granger causality }\end{array}$ & Pollution halo \\
\hline Mutafoglu (2012) & Turkey & 1987Q1-2009Q4 & $\begin{array}{l}\text { Johansen co-integration and Granger cau- } \\
\text { sality }\end{array}$ & Pollution haven \\
\hline
\end{tabular}

Note: $N A$ indicates no definite result 
We firstly performed unit root tests to analyze the stationarities of both series, employing the Phillips-Perron (PP) (Phillips and Perron 1988) and Ng-Perron (Ng-P) tests (Ng and Perron 2001). Furthermore, to analyze the structural breaks in the series, we used the Zivot and Andrews (ZA) unit root test (1992), which allows one structural break in the series, as well as the Narayan and Popp (2010) unit root (NP) test, which allows two structural breaks.

To study the short-run asymmetric causal relationships between the series, we employed the Hatemi-J (2012, HJ) test. According to the standard procedure for this test, we could write the series as Eqs. 1 and 2 if the series are $I(1)$ :

$$
\begin{aligned}
& \mathrm{CO}_{2 t}=\mathrm{CO}_{2 t-1}+\varepsilon_{1 t}=\mathrm{CO}_{20}+\sum_{i=1}^{t} \varepsilon_{1 i} \\
& \mathrm{FDI}_{t}=\mathrm{FDI}_{t-1}+\varepsilon_{2 t}=\mathrm{FDI}_{0}+\sum_{i=1}^{t} \varepsilon_{2 i}
\end{aligned}
$$

In Eqs. 1 and 2, $\mathrm{CO}_{20}$ and $\mathrm{FDI}_{0}$ represent initial values, while series $\varepsilon_{1 t}$ and $\varepsilon_{2 t}$ are white noise. The positive and negative shocks of the series are represented as $\varepsilon_{1 i}^{+}=\max \left(\varepsilon_{1 i}, 0\right)$, $\varepsilon_{2 i}^{+}=\max \left(\varepsilon_{2 i}, 0\right), \varepsilon_{1 i}^{-}=\min \left(\varepsilon_{1 i}, 0\right)$, and $\varepsilon_{2 i}^{-}=\min \left(\varepsilon_{2 i}, 0\right)$ (Nasir et al. 2020). Decomposing these shocks allows them to be rewritten as $\varepsilon_{1 i}=\varepsilon_{1 i}^{+}+\varepsilon_{1 i}^{-}$and $\varepsilon_{2 i}=\varepsilon_{2 i}^{+}+\varepsilon_{2 i}^{-}$. The cumulative positive and negative shocks of the series could be represented as in Eqs. 3-6:

$$
\begin{aligned}
& \mathrm{CO}_{2 t}^{+}=\sum_{i=1}^{t} \varepsilon_{1 i}^{+} \\
& \mathrm{CO}_{2 t}^{-}=\sum_{i=1}^{t} \varepsilon_{1 i}^{-} \\
& \mathrm{FDI}_{t}^{+}=\sum_{i=1}^{t} \varepsilon_{2 i}^{+} \\
& \mathrm{FDI}_{t}^{-}=\sum_{i=1}^{t} \varepsilon_{2 i}^{-}
\end{aligned}
$$

According to the $\mathrm{HJ}$ test procedure, the cumulative shocks are then represented as a VAR model with $p$ lags. The lag $p$ is a lag in a VAR model that meets all stability conditions; it is determined by criteria such as AIC or SC. The HJ test uses a Wald test statistic (W-stat.) to test asymmetric causality between the cumulative shocks with bootstrap-critical values (Hatemi-J 2012).
The asymmetric pollution halo and the asymmetric pollution haven hypotheses are defined in Table 2, which assumes FDI shocks are independent variables, whereas $\mathrm{CO}_{2}$ shocks are assumed to serve as the dependent variables in the longrun equations. Furthermore, the coefficients for the shocks of FDI in the equations are assumed to be statistically significant. Thus, eight different equations could be obtained to test asymmetric hypotheses by the end of the procedure.

The pollution haven hypothesis claims that foreign direct investments lead to increased emissions, while the pollution halo hypothesis posits that the foreign direct investments lead to a decline in emissions. Thus, for cases 1 and 3 in Table 2, any shock (positive or negative) to foreign direct investments leads to an increase in the positive movements of emissions, thus confirming the validity of the asymmetric pollution haven hypothesis in those cases. In cases 6 and 8 in the table, any shock to the foreign direct investments induces a decrease in emission decrease. This means that the shocks of the foreign direct investments will brake on emission downturn. Thus, the asymmetric pollution haven hypothesis would be valid in cases 6 and 8 . However, in cases 2 and 4, any shock to foreign direct investments causes a decline in emission growth. That is, the shocks of the foreign direct investments will brake on emission rises. Consequently, cases 2 and 4 would support the asymmetric pollution halo hypothesis. According to cases 5 and 7, any shock to foreign direct investments causes an increase in emission decline. Thus, foreign direct investment shocks should lead to a downturn in emissions, providing evidence for the validity of the asymmetric pollution halo hypothesis.

To reveal long-run asymmetric relationships between the series, we performed hidden co-integration techniques by Granger and Yoon (2002) and Hatemi-J and Irandost (2012). These procedures use the cumulative shocks represented in Eqs. 3-5 as the variables in the long-run and short-run equations. Granger and Yoon's (2002) hidden co-integration employs Engle and Granger's (1987) co-integration technique while Hatemi-J and Irandost (2012) use the Johansen (1996)

Table 2 Definitions of asymmetric pollution haven/halo hypotheses

\begin{tabular}{lllll}
\hline Case & Sign $^{\mathrm{a}}$ & Shocks of FDI & Shocks of $\mathrm{CO}_{2}$ & Hypothesis \\
\hline 1 & + & $\mathrm{FDI}^{+}$ & $\mathrm{CO}_{2}^{+}$ & Asymmetric pollution haven \\
2 & - & $\mathrm{FDI}^{+}$ & $\mathrm{CO}_{2}^{+}$ & Asymmetric pollution halo \\
3 & + & $\mathrm{FDI}^{-}$ & $\mathrm{CO}_{2}^{+}$ & Asymmetric pollution haven \\
4 & - & $\mathrm{FDI}^{-}$ & $\mathrm{CO}_{2}^{+}$ & Asymmetric pollution halo \\
5 & + & $\mathrm{FDI}^{+}$ & $\mathrm{CO}_{2}^{-}$ & Asymmetric pollution halo \\
6 & - & $\mathrm{FDI}^{+}$ & $\mathrm{CO}_{2}^{-}$ & Asymmetric pollution haven \\
7 & + & $\mathrm{FDI}^{-}$ & $\mathrm{CO}_{2}^{-}$ & Asymmetric pollution halo \\
8 & - & $\mathrm{FDI}^{-}$ & $\mathrm{CO}_{2}^{-}$ & Asymmetric pollution haven \\
\hline
\end{tabular}

${ }^{a}$ Sign of the coefficient of the shocks of FDI variable in the long-run equation 
vector error correction models (VECMs) to derive the longand short-run equations. To evaluate the long-run asymmetric causal relationship between the cumulative shocks, we estimated the crouching error correction model (CECM) after performing Granger and Yoon's (2002) hidden cointegration test and estimated the VECM after performing Hatemi-J and Irandost (2012) hidden co-integration test.

\section{Findings}

We performed the PP and Ng-P tests to analyze the unit root of the series. The results of these tests can be seen in Table 3 . They show that the levels of the $\mathrm{CO}_{2}$ and FDI series are nonstationary, but their first differences are stationary.

In addition to the PP and Ng-P tests, we performed ZA and NP tests to check for the presence of any significant structural breaks in the series. Ordinary unit root tests such as PP and Ng-P cannot reject the unit root null hypothesis as they do not consider structural breaks. If significant structural breaks exist in the series, ordinary unit root tests can find the series to be non-stationary even if it is stationary. Thus, to ensure a more robust decision about the existence of a unit root in a series, the unit root tests with structural breaks should be performed after the ordinary unit root tests, especially if ordinary root tests find that the series is non-stationary. Table 4 provides the results of these unit root tests with structural breaks. According to these results, the unit root hypothesis cannot be rejected; thus, we conclude that no significant structural breaks in the series exist.

From these unit root test results, we concluded that the series $\mathrm{CO}_{2}$ and FDI are $I(1)$, so the $\mathrm{HJ}$ test can be performed to estimate the short-run asymmetric causal relationship. To do so, we obtain the cumulative shocks of the series given in Eqs. 3-5. The lag value is determined from the VAR model, which meets all the stability conditions based on the AIC statistic. The HJ test results can be seen in Table 5 .

Table 3 Unit root process

\begin{tabular}{lllll}
\hline PP test & Adj. $\boldsymbol{t}$-stat. & & & \\
$\mathrm{CO}_{2}$ & -3.43 & & & \\
$\Delta \mathrm{CO}_{2}$ & $-8.20^{* *}$ & & & \\
$\mathrm{FDI}$ & -2.61 & & & \\
$\Delta$ FDI & $-10.78^{* *}$ & & & \\
$\mathbf{N g}-P$ test & $\mathbf{M Z a}$ & $\mathbf{M Z t}$ & MSB & MPT \\
$\mathrm{CO}_{2}$ & -14.11 & -2.63 & 0.19 & 6.59 \\
$\Delta \mathrm{CO}_{2}$ & $-21.09^{*}$ & $-3.24^{*}$ & $0.15^{*}$ & $4.38^{*}$ \\
$\mathrm{FDI}$ & -11.31 & -2.37 & 0.21 & 8.07 \\
$\Delta \mathrm{FDI}$ & $-1428.34^{* *}$ & $-26.72^{* *}$ & $0.02^{* *}$ & $0.06^{* *}$ \\
\hline
\end{tabular}

The models with trend and intercept are used

*Significant at .05 level; **significant at .01 level
Table 4 Unit root with structural breaks

\begin{tabular}{lllll}
\hline ZA test & $t$-stat. & $T_{\mathrm{b}}$ & Lag & \\
\hline $\mathrm{CO}_{2}$ & -4.61 & 1985 & 0 & \\
FDI & -5.50 & 2006 & 6 & \\
NP test & $\boldsymbol{t}$-stat. & $\boldsymbol{T}_{\mathbf{b} 1}$ & $\boldsymbol{T}_{\mathbf{b} 2}$ & $\mathbf{L a g}$ \\
$\mathrm{CO}_{2}$ & -3.94 & 1993 & 2000 & 0 \\
FDI & -3.67 & 2005 & 2008 & 3 \\
\hline
\end{tabular}

Notes: Model C is used. Max. lag is 6 . The 0.01 critical value for ZA test is -5.570 . The 0.01 critical value for NP test is -5.576

As seen from the results in Table 5, we found an asymmetric causality from the positive shocks of foreign direct investments to positive shocks of emissions. In other words, positive shocks to foreign direct investment cause positive shocks to the emissions in the short run. These results indicate that emission reduction policies that rely on FDI will actually induce increased $\mathrm{CO}_{2}$ emissions in the short run in Turkey. Thus, policymakers in Turkey must employ long-term policies to achieve the emissions targets. In addition, this study examines long-term relationships between FDI and $\mathrm{CO}_{2}$ emissions to guide policymakers in forming long-term policies.

To estimate long-run asymmetric causal relationships between the series, we performed the Granger and Yoon (2002) hidden co-integration (GY) test based on the co-integration procedure from Engle and Granger (1987). We began by performing unit root tests for positive and negative cumulative shock series given in Eqs. 3-5, concluding that all the cumulative shocks were $I(1)$. These results are not shown here to conserve space. We then performed a $\mathrm{GY}$ test for the functions $\mathrm{CO}_{2}^{+}=f\left(\mathrm{FDI}^{+}\right), \mathrm{CO}_{2}^{+}=f\left(\mathrm{FDI}^{-}\right), \mathrm{CO}_{2}^{-}=f\left(\mathrm{FDI}^{+}\right)$, and $\mathrm{CO}_{2}^{-}=f\left(\mathrm{FDI}^{-}\right)$with model $\mathrm{A}$ (model with intercept) and model $\mathrm{C}$ (model with intercept and trend). With the GY test, we found a co-integration only for the function $\mathrm{CO}_{2}^{+}=f$ $\left(\mathrm{FDI}^{+}\right)$with model C. This result is shown in Table 6.

According to the $Z$-statistic given in Table 6 , the series are co-integrated at the .10 level if the series $\mathrm{CO}_{2}^{+}$is a dependent variable in the long-run equation. These long-run estimation results can be seen in Table 6. The residuals of this long-run estimation are normally distributed. We tested the normality of the residuals with the Jarque-Bera test. We also calculated a $\mathrm{HAC}$ variance-covariance matrix to correct any possible heteroscedasticity or autocorrelation in residuals. The longrun estimation results demonstrate that all coefficients are statistically significant. The coefficient of $\mathrm{FDI}^{+}$is -0.221 , which corresponds to the second case in Table 2 and means that a $1 \%$ increase in the positive shocks of the foreign direct investments will decrease the positive shocks of emissions by $0.221 \%$. In other words, the positive improvements in the foreign direct investments will lead to a decrease in emission increase. This result supports the validity of the asymmetric 
Table 5 Short-run asymmetric causality results

\begin{tabular}{llllll}
\hline $\mathrm{HJ}$ test & \multicolumn{5}{c}{ Bootstrap critical values } \\
\hline Direction & W-stat. & $1 \%$ & $5 \%$ & $10 \%$ & Causality \\
$\mathrm{FDI}^{+} \neq>\mathrm{CO}_{2}^{+}$ & $13.483^{*}$ & 16.719 & 9.076 & 3.464 & 3.232 \\
$\mathrm{FDI}^{-} \neq>\mathrm{CO}_{2}^{-}$ & 0.033 & 10.965 & 5.104 & 3.606 & No \\
$\mathrm{FDI}^{+} \neq>\mathrm{CO}_{2}^{-}$ & 0.400 & 10.275 & 5.244 & 3.090 & No \\
$\mathrm{FDI}^{-} \neq>\mathrm{CO}_{2}^{+}$ & 0.828 & 8.848 & 4.647 & No \\
\hline
\end{tabular}

$\not>$ means that there is no asymmetric causality. Bootstrap critical values are obtained based on 10,000 replications. Max. lag values are chosen according to AIC

*Significant at .05 level

pollution halo hypothesis in Turkey, confirming that FDI inflows contribute to Turkey's emissions targets. Policymakers who focus on environmental standards should thus encourage more investors to invest in Turkey through economic incentives such as tax breaks.

To estimate the CECM, Eqs. 7 and 8 can be derived as below (Granger and Yoon 2002):

$$
\begin{aligned}
\Delta \mathrm{CO}_{2 t}^{+}= & \psi_{0}+\psi_{1} \widehat{\varepsilon}_{t-1}+\sum_{i=1}^{k} \psi_{i} \Delta \mathrm{FDI}_{t-i}^{+} \\
& +\sum_{j=1}^{p} \psi_{j} \Delta \mathrm{CO}_{2 t-j}^{+}+v_{t} \\
\Delta \mathrm{FDI}_{t}^{+}= & \gamma_{0}+\gamma_{1} \widehat{\varepsilon}_{t-1}+\sum_{i=1}^{k} \gamma_{i} \Delta \mathrm{FDI}_{t-i}^{+} \\
& +\sum_{j=1}^{p} \gamma_{j} \Delta \mathrm{CO}_{2 t-j}^{+}+v_{t}
\end{aligned}
$$

In Eqs. 7 and 8, $\widehat{\varepsilon}_{t-1}$ represents the one-lagged residuals of the estimated long-run equation in Table 6 . The coefficients $\psi_{1}$ and $\gamma_{1}$ represent the long-run adjustments, while the coefficients of the lagged differenced variables stand for the shortrun adjustments. Many studies, like Granger and Yoon (2002) and Honarvar (2009), only report the significant coefficients resulting from these CECM equations. To obtain equations with the significant coefficients, stepwise regression is performed in the current study. We set the maximum lag value (the value of $k$ and $p$ ) at 10 and applied the stepwise regression with backward selection at the .10 significance level to estimate the parameters of the CECM equations that are statistically significant at the .10 level. The results of this estimation are given in Table 7 .

In the short-run equations given in Table 7, all coefficients are significant at the .10 level because of the stepwise regression procedure. Gonzalo and Granger (1995) defined the dependent variable of the CECM equation with an insignificant error correction coefficient as a permanent component. Permanent component variables are responsible for the longrun dynamics between the variables. Any shock to the permanent component will affect both itself and the other variables in the long run. On the contrary, a dependent variable in the CECM equation with a significant error correction coefficient is defined as transitory (Gonzalo and Granger 1995). A transitory variable will not determine long-run dynamics; thus, any shock to the transitory variable will be impermanent in the long run. The results in Table 7 demonstrate that the coefficient of error correction is insignificant for the short-run equation of $\mathrm{FDI}^{+}$and the coefficient of error correction is negative and significant (coef. $=-0.68$ and $P<.10$ ) as expect-

\begin{tabular}{|c|c|c|c|c|}
\hline Dependent variable & tau-stat. & $P$ value & $z$-stat. & $P$ value \\
\hline $\mathrm{CO}_{2}^{+}$ & -3.66 & 0.100 & $-20.23^{*}$ & 0.097 \\
\hline $\mathrm{FDI}^{+}$ & -1.37 & 0.949 & -4.52 & 0.945 \\
\hline \multicolumn{5}{|l|}{ Co-integration equation } \\
\hline Dependent variable: $\mathrm{CO}_{2}^{+}$ & Coef. & St. error & $t$-stat. & $P$ value \\
\hline Constant & 0.0497 & 0.0118 & $2.13 * *$ & 0.038 \\
\hline Trend & 0.0367 & 0.0006 & $35.32 * * *$ & 0.000 \\
\hline $\mathrm{FDI}^{+}$ & -0.2210 & 0.0765 & $-2.22 * *$ & 0.031 \\
\hline
\end{tabular}
ed for the short-run equation of $\mathrm{CO}_{2}^{+}$; thus, the series $\mathrm{FDI}^{+}$is a permanent component while the series $\mathrm{CO}_{2}^{+}$is transitory in the

Table 6 GY Hidden co-integration results for $\mathrm{CO}_{2}^{+}=f\left(\mathrm{FDI}^{+}\right)$

Model C (intercept and trend) is used for the co-integration equation

*Significant at .10 level; **significant at .05 level; ***significant at .01 level 
Table 7 Crouching error correction model results

$\Delta \mathrm{CO}_{2 t}^{+}=0.19 \Delta \mathrm{CO}_{2 t-1}^{+}+0.37 \Delta \mathrm{CO}_{2 t-3}^{+}+0.24 \Delta \mathrm{CO}_{2 t-4}^{+}+0.19 \Delta \mathrm{CO}_{2 t-7}^{+}-0.50 \Delta \mathrm{FDI}_{t-1}^{+}-0.68 \widehat{\varepsilon}_{t-1}, \bar{R}^{2}=0.30$

$\Delta \mathrm{FDI}_{t}^{+}=0.17 \Delta \mathrm{CO}_{2 t-2}^{+}+0.31 \Delta \mathrm{FDI}_{t-5}^{+}+0.30 \Delta \mathrm{FDI}_{t-7}^{+}-0.64 \Delta \mathrm{FDI}_{t-9}^{+}+2.42 \Delta \mathrm{FDI}_{t-10}^{+}, \bar{R}^{2}=0.29$

long run. Positive shocks in foreign direct investments determine long-run dynamics. These results demonstrate that an asymmetric long-run causality from $\mathrm{FDI}^{+}$to $\mathrm{CO}_{2}^{+}$. Furthermore, in the equation of the emissions, the coefficient of foreign direct investment is negative and significant (coef. $=-0.50$ and $P<.10$ ) in Table 7 . Thus, a positive movement in foreign direct investments will lead to a decrease in the growth rate of emissions in the short run. This result parallels the results of the long-run equation. In both the short and long runs, policymakers should aim to encourage FDI in Turkey.

We also analyzed hidden co-integration between the series with the Hatemi-J and Irandost (2012) VCEM methodology to obtain robust results. For this purpose, we estimated VECM models for the functions $\mathrm{CO}_{2}^{+}=f\left(\mathrm{FDI}^{+}\right), \mathrm{CO}_{2}^{+}=f\left(\mathrm{FDI}^{-}\right)$, $\mathrm{CO}_{2}^{-}=f\left(\mathrm{FDI}^{+}\right)$, and $\mathrm{CO}_{2}^{-}=f\left(\mathrm{FDI}^{-}\right)$. We used the model with only an intercept in the co-integration equation $(\mathrm{CE})$ and no intercept in VAR, the model with an intercept in CE and VAR and the model with intercept, and trend in CE and no trend in VAR. We only found a co-integration relationship for the function $\mathrm{CO}_{2}^{+}=f\left(\mathrm{FDI}^{-}\right)$with the model intercept in $\mathrm{CE}$ and VAR; the lag value was determined as 6 by using AIC and BIC statistics. In this VECM estimation, no serial correlation or heteroscedasticity existed and the residuals were normally distributed. The estimation results of $\operatorname{VECM}(6)$ can be seen in Table 8.

In the long-run estimation as seen in Table 8 , the coefficient of the series $\mathrm{FDI}^{-}$is insignificant (Coef. = -0.9505 and $t$-stat. $=1.28(P>.10))$ so we cannot conclude that either the asymmetric pollution haven or the pollution halo hypothesis is valid. However, the coefficient of the error correction in the short-run equation is negative and significant (Coef. $=-0.06$ and $t$-stat. $=$ $-2.39(P<.05))$. This negative and significant error correction coefficient means that there is an asymmetric long-run causality from the negative shocks of the foreign direct investments to the positive shocks of emissions. Despite the insignificant effects of the negative movements of FDI in the long run, the effect of the negative movements of FDI on the positive movements of emissions is negative and significant in the short run (Coef. $=-0.443$ and $t=-2.31(P<.05)$ ). Furthermore, the coefficient of error correction term is close to zero (Coef. $=-0.06$ ), thus demonstrating the slow speed to reach the equilibrium (long-run) level. Short-run imbalances will be adjusted by $0.06 \%$ within the first year, but reaching long-run level will require about 17 years. Thus, the significant effects of $\mathrm{FDI}^{-}$on
$\mathrm{CO}_{2}^{+}$in the short run will become insignificant after a long time. As a result, the short-run regulations in foreign direct investments also play an important role in reaching emission targets for Turkey.

\section{Discussion}

In this study, we test the asymmetric pollution halo and asymmetric pollution haven hypotheses for Turkey by using the data from 1974-2018. We estimate short- and long-run asymmetric causal relationships between the positive and the negative movements in foreign direct investments and emissions. We perform hidden co-integration techniques and estimate vector and crouching error correction models. We finally perform stepwise regression to estimate crouching error correction models and define the long-run asymmetric causality based on the error correction models.

The unit root process indicated that the foreign direct investments and emissions series in Turkey are both non-stationary. This result is consistent with the findings in Akbostanc1 et al. (2007), Mutafoglu (2012), Seker et al. (2015), Ozturk and Oz (2016), Koçak and Şarkgüneşi (2018), and Terzi and Pata (2019). The unit roots of these series signify their lack of resistance to a given random shock; their level will not reach the ex-level in the long run. These findings indicate that Turkey can form policies on foreign direct investments to decrease its levels of emissions.

The short-run causality results indicate an asymmetric causal link between positive shocks in foreign direct investments and positive movements in emissions $\left(\mathrm{FDI}^{+} \rightarrow \mathrm{CO}_{2}^{+}\right)$. In the long run, positive shocks in foreign direct investments are asymmetrically causally related to positive movements in emissions $\left(\mathrm{FDI}^{+} \rightarrow \mathrm{CO}_{2}^{+}\right)$while negative shocks in foreign direct investments also demonstrate an asymmetrical causal relationship with positive movements in emissions $\left(\mathrm{FDI}^{-} \rightarrow \mathrm{CO}_{2}^{+}\right)$. Consequently, any shock (positive or negative) to foreign direct investments in Turkey will also determine emission growth in the long run, while positive shocks in foreign direct investments in Turkey will determine emission growth in the short run. From this perspective, policies on both short- and long-run foreign direct investments should determine the emission targets in Turkey.

The result of hidden co-integration analyses indicates that $\left[\mathrm{FDI}^{+}, \mathrm{CO}_{2}^{+}\right]$and $\left[\mathrm{FDI}^{-}, \mathrm{CO}_{2}^{+}\right]$are co-integrated. In Turkey, positive movements in both foreign direct investments and 
Table 8 Hatemi J-Irandost hidden co-integration results for $\mathrm{CO}_{2}^{+}=f\left(\mathrm{FDI}^{-}\right)$

\begin{tabular}{llll}
\hline $\begin{array}{l}\text { Long-run equation of VECM(6) } \\
\text { Dependent variable: } \mathbf{C O}_{2}^{+}\end{array}$ & Coef. & St. error & $t$-stat. \\
Constant & 0.8438 & - & - \\
FDI & -0.9505 & 0.74 & 1.28 \\
Short-run equation of VECM(6) & & & \\
Dependent variable: $\Delta \mathbf{C O}_{2 t}^{+}$ & Coef. & St. error & $t$-stat. \\
$\widehat{\varepsilon}_{t-1}$ & $-0.06^{*}$ & 0.023 & -2.39 \\
$\Delta \mathrm{CO}_{2 t-1}^{+}$ & -0.292 & 0.183 & -1.60 \\
$\Delta \mathrm{CO}_{2 t-2}^{+}$ & $-0.395^{*}$ & 0.179 & -2.20 \\
$\Delta \mathrm{CO}_{2 t-3}^{+}$ & 0.004 & 0.175 & 0.02 \\
$\Delta \mathrm{CO}_{2 t-4}^{+}$ & -0.137 & 0.173 & -0.79 \\
$\Delta \mathrm{CO}_{2 t-5}^{+}$ & -0.172 & 0.171 & -1.01 \\
$\Delta \mathrm{CO}_{2 t-6}^{+}$ & -0.266 & 0.169 & -1.57 \\
$\Delta \mathrm{FDI}_{t-1}^{-}$ & $-0.443^{*}$ & 0.192 & -2.31 \\
$\Delta \mathrm{FDI}_{t-2}^{-}$ & -0.105 & 0.205 & -0.51 \\
$\Delta \mathrm{FDI}_{t-3}^{-}$ & -0.102 & 0.205 & -0.49 \\
$\Delta \mathrm{FDI}_{t-4}^{-}$ & 0.376 & 0.239 & 1.57 \\
$\Delta \mathrm{FDI}_{t-5}^{-}$ & -0.139 & 0.265 & -0.52 \\
$\Delta \mathrm{FDI}_{t-6}^{-}$ & -0.044 & 0.255 & -0.17 \\
$\mathrm{Constant}^{-}$ & $0.075^{* *}$ & 0.019 & 3.82 \\
\hline $\mathrm{AC}^{-}$ & & & \\
\hline & & &
\end{tabular}

$\mathrm{AIC}=-7.99, \mathrm{BIC}=-6.68$

*Significant at .05 level; **significant at .01 level

emissions act in tandem, whereas negative movements in foreign direct investments and positive movements in emissions move together in the long run. Thus, Turkey could effectively reach its emissions target by implementing FDI policies.

This study mainly contributes to the literature by testing the asymmetric pollution haven and the asymmetric pollution halo hypotheses. The hidden co-integration analyses we performed demonstrate the validity of the asymmetric pollution halo hypothesis in Turkey, therefore signifying that increases in foreign direct investments in Turkey will lead to a decline in emission growth in the long run. This result contradicts the studies by Akbostanc1 et al. (2007), Mutafoglu (2012), Seker et al. (2015), Kocak and Şarkgunesi (2018), and Terzi and Pata (2019), which support the pollution haven hypothesis for Turkey, although those studies tested the pollution hypotheses symmetrically, rather than asymmetrically like this study.

We also estimated the crouching error correction model. To the best of our knowledge, all previous studies have set the maximum lag number as 4 in the literature because higher lag numbers would require too much time to solve the model. This study also contributes to the literature by using stepwise regression to more easily estimate the parameters in the crouching error correction model even with high lag numbers based on the study by Mert and Caglar (2019). The results of these estimations indicate that foreign direct investments are permanent while emissions are transitory in the long run. Thus, foreign direct investments are responsible for the longrun dynamics, and a shock to foreign direct investments in Turkey will affect both its future value as well as that of emissions.

Our study then contributed to the current literature by concluding that positive movements in foreign direct investments asymmetrically cause positive long-run movements in emissions. Policymakers should take note of the finding that the series $\mathrm{FDI}^{+}$is a permanent component and responsible for long-run dynamics in the decline in emission growth. As well, the CECM results show that the positive movements of the foreign direct investments negatively and significantly impact the positive movements of emissions in the short run. In addition to these findings, the VECM estimation results also demonstrate that the negative movements in foreign direct investments asymmetrically cause positive movements of emissions in the long run; further, negative movements in foreign direct investments negatively and significantly affect the positive movements of emissions in the short run.

When implementing policies to encourage FDI inflows in Turkey, policymakers should implement the following environmentally friendly policies: encouraging investors to import green technology, prioritizing FDI inflows that will ensure environmental protection and economic development, and privileging investors who will contribute to meeting Turkey's emission reduction targets. Importantly, this study also shows that any movement (positive or negative) of FDI is the main determinant for a decline in the rate of emissions growth in Turkey. As a result, Turkey should attempt to enhance FDI inflows to achieve its emission reduction targets. Authorities should develop policies aimed at not only increasing FDI inflows in Turkey but also protecting the environment in both the short and long runs. Since the global COVID-19 outbreak can be considered an effective shock to FDI as well as other important variables, it will affect Turkey's ability to protect the environment in both the short and long term. Since our study's findings provide evidence that FDI inflows impact emissions, Turkey's policymakers should be prepared for the possible scenarios that may result from this epidemic.

Given the increasing strength of inter-country relations in an ever more global world, future studies seeking to explore the FDI-emission relationship should focus on unions such as the OECD, EU, G20, and MENA. New studies on this relationship should consider the asymmetric effects of FDI for these countries with common characteristics. These studies should examine cross-section dependency, which may play an important role in the relationship between FDI flows and $\mathrm{CO}_{2}$ emissions.

Funding information This study was supported by the Scientific Research Projects Coordination Unit of Akdeniz University in Turkey. (Project Number: SBG-2020-5189). 


\section{References}

Akbostancı E, Tunc GI, Türüt-Așık S (2007) Pollution haven hypothesis and the role of dirty industries in Turkey's exports. Environ Dev Econ 12(2):297-322

Albulescu CT, Tiwari AK, Yoon SM, Kang SH (2019) FDI, income, and environmental pollution in Latin America: Replication and extension using panel quantiles regression analysis. Energy Econ 104504

Alexakis C, Dasilas A, Grose C (2013) Asymmetric dynamic relations between stock prices and mutual fund units in Japan. An application of hidden cointegration technique. International Review of Financial Analysis 28:1-8

Al-Mulali U, Ozturk I (2015) The effect of energy consumption, urbanization, trade openness, industrial output, and the political stability on the environmental degradation in the MENA (Middle East and North African) region. Energy 84:382-389

Alom F, Ritson N (2012) Asymmetric adjustment of diesel or petrol retail prices to crude oil price movements: new Zealand evidence. OPEC Energy Review 36(2):230-245

Baek J (2016) A new look at the FDI-income-energy-environment nexus: dynamic panel data analysis of ASEAN. Energy Policy 91:22-

Bakirtas I, Cetin MA (2017) Revisiting the environmental Kuznets curve and pollution haven hypotheses: MIKTA sample. Environmental Science and Pollution Research 24(22):18273-18283

Balsalobre-Lorente D, Gokmenoglu KK, Taspinar N, Cantos-Cantos JM (2019) An approach to the pollution haven and pollution halo hypotheses in MINT countries. Environ Sci Pollut Res:1-17

Bello A, Adeniyi O (2010) FDI and the environment in developing economies: evidence from Nigeria. Environ Res J 4(4):291-297

Boden TA, Marland G, Andres RJ (2009) Global, regional, and national fossil-fuel Co2 emissions. Carbon Dioxide Information Analysis Center, Oak Ridge National Laboratory, U.S. Department of Energy, Oak Ridge, Tenn., U.S.A. https://doi.org/10.3334/CDIAC/ 00001

BP (2019) Statistical review of world energy. [Access: 20.08.2019]. https://www.bp.com/en/global/corporate/energy-economics/ statistical-review-of-world-energy.html

Butler JH, Montzka SA (2019) The Noaa Annual Greenhouse Gas Index (AGGI) 2019. [Access: 06.11.2019]. https://www.esrl.noaa.gov/ gmd/aggi/aggi.html

Caglar AE (2020) The importance of renewable energy consumption and FDI inflows in reducing environmental degradation: bootstrap ARDL bound test in selected 9 countries. J Cleaner Prod 121663

Cai Y, Chang T, Inglesi-Lotz R (2018) Asymmetric persistence in convergence for carbon dioxide emissions based on quantile unit root test with Fourier function. Energy 161:470-481

Center for Global Development (2015) [Access: 10.10.2019]. https:// www.cgdev.org/media/developing-countries-are-responsible-63percent-current-carbon-emissions

Central Bank of the Republic of Turkey (2019) Electronic Data Delivery System. [Access: 03.08.2019]. https://www.tcmb.gov.tr/wps/wcm/ connect/EN/TCMB+EN/Main+Menu/Statistics

Destek MA, Okumus I (2019) Does pollution haven hypothesis hold in newly industrialized countries? Evidence from ecological footprint. Environ Sci Pollut Res:1-7

Engle RF, Granger CW (1987) Co-integration and error correction: representation, estimation, and testing. Econometrica: journal of the Econometric Society 55:251-276

EY (2019) How can Europe raise its game. Attractiveness surveys. [Access: 01.08.2019]. https://www.ey.com/en_gl/attractiveness

Gonzalo J, Granger CW (1995) Estimation of common long-memory components in cointegrated systems. J Bus Econ Stat 13:27-35
Gorus MS, Aslan M (2019) Impacts of economic indicators on environmental degradation: evidence from MENA countries. Renewable and Sustainable Energy Reviews 103:259-268

Granger CW, Yoon G (2002) Hidden cointegration. U of California, Economics Working Paper 02

Grossman GM, Krueger AB (1991) Environmental impacts of a North American free trade agreement (No. w3914). National Bureau of Economic Research

Hao Y, Liu YM (2015) Has the development of FDI and foreign trade contributed to China's CO 2 emissions? An empirical study with provincial panel data. Natural Hazards 76(2):1079-1091

Hatemi-J A, Irandoust M (2012) Asymmetric interaction between government spending and terms of trade volatility: new evidence from hidden cointegration technique. J Econ Stud 39(3):368-378

Hatemi-J A (2012) Asymmetric causality tests with an application. Empir Econ 43:447-456

Honarvar A (2009) Asymmetry in retail gasoline and crude oil price movements in the United States: an application of hidden cointegration technique. Energy Econ 31:395-402

International Energy Agency (2018) Global energy \& Co2 status report. Global Energy \& CO2 Status Report. 2018 (March):1-15.

Johansen S (1996) Likelihood-based inference in cointegrated vector auto-regressive models, 2nd edn. Oxford University Press

K1lıçarslan Z, Dumrul Y (2017) Foreign direct investments and CO2 emissions relationship: the case of Turkey. Bus Econ Res J 8(4): 647-660

Kivyiro P, Arminen H (2014) Carbon dioxide emissions, energy consumption, economic growth, and foreign direct investment: causality analysis for sub-Saharan Africa. Energy 74:595-606

Koçak E, Şarkgüneși A (2018) The impact of foreign direct investment on $\mathrm{CO} 2$ emissions in Turkey: new evidence from cointegration and bootstrap causality analysis. Environ Sci Pollut Res 25:790-804

Koutroulis A, Panagopoulos Y, Tsouma E (2016) Asymmetry in the response of unemployment to output changes in Greece: evidence from hidden co-integration. The Journal of Economic Asymmetries 13:81-88

Lau LS, Choong CK, Eng YK (2014) Investigation of the environmental Kuznets curve for carbon emissions in Malaysia: do foreign direct investment and trade matter? Energy Policy 68:490-497

Lee JW (2013) The contribution of foreign direct investment to clean energy use, carbon emissions and economic growth. Energy Policy 55:483-489

Merican Y, Yusop Z, Noor ZM, Hook LS (2007) Foreign direct investment and the pollution in five ASEAN nations. Int J Econ Manag 1(2):245-261

Mert M, Bölük G (2016) Do foreign direct investment and renewable energy consumption affect the $\mathrm{CO} 2$ emissions? New evidence from a panel ARDL approach to Kyoto Annex countries. Environ Sci Pollut Res 23(21):21669-21681

Mert M, Çağlar AE (2019) Eviews ve Gauss Uygulamalı Zaman Serileri Analizi. Detay Yayınc1lik, Ankara. isbn:978-605-254-126-5

Mert M, Bölük G, Cağlar AE (2019) Interralationships among foreign direct investments, renewable energy, and $\mathrm{CO} 2$ emissions for different European country groups: a panel ARDL approach. Environ Sci Pollut Res 26:21495-21510

Mutafoglu TH (2012) Foreign direct investment, pollution, and economic growth evidence from Turkey. Journal of Developing Societies 28(3):281-297

Narayan PK, Popp S (2010) A new unit root test with two structural breaks in level and slope at unknown time. J. Appl. Stat 37(9): $1425-1438$

Nasir MA, Lorente DB, Huynh TLD (2020) Anchoring inflation expectations in the face of oil shocks \& in the proximity of ZLB: a tale of two targeters. Energy Economics 86

$\mathrm{Ng} \mathrm{S}$, Perron P (2001) Lag length selection and the construction of unit root tests with good size and power. Econometrica 69:1519-1554 
Öztürk Z, Öz D (2016) The relationship between energy consumption, income, foreign direct investment, and $\mathrm{CO} 2$ emissions: the case of Turkey. Çankırı Karatekin University Journal of the Faculty of Economics and Administrative Sciences 6(2):269-288

Peters GP, Hertwich EG (2008) CO2 embodied in international trade with implications for global climate policy. Environ Sci Technol 42: 1401-1407

Peters GP, Minx JC, Weber CL, Edenhofer O (2011) Growth in emission transfers via international trade from 1990 to 2008. Proceedings of the national academy of sciences 108(21):8903-8908

Phillips PCB, Perron P (1988) Testing for a unit root in time series regression. Biometrika 75:335-346

Rafindadi AA, Muye IM, Kaita RA (2018) The effects of FDI and energy consumption on environmental pollution in predominantly resource-based economies of the GCC. Sustainable Energy Technologies and Assessments 25:126-137

Rana R, Sharma M (2019) Dynamic causality testing for EKC hypothesis, pollution haven hypothesis and international trade in India. The Journal of International Trade \& Economic Development 28(3): 348-364

Seker F, Ertugrul HM, Cetin M (2015) The impact of foreign direct investment on environmental quality: a bounds testing and causality analysis for Turkey. Renew Sust Energ Rev 52:347-356

Shaari MS, Hussain NE, Abdullah H, Kamil S (2014) Relationship among foreign direct investment, economic growth and $\mathrm{CO} 2$ emission: a panel data analysis. Int J Energy Econ Policy 4(4):706-715

Shahbaz M, Nasreen S, Abbas F, Anis O (2015) Does foreign direct investment impede environmental quality in high-, middle-, and low-income countries? Energy Econ 51:275-287
Shahbaz M, Nasir MA, Roubaud D (2018) Environmental degradation in France: the effects of FDI, financial development, and energy innovations. Energy Economics 74:843-857

Solarin SA, Al-Mulali U, Musah I, Ozturk I (2017) Investigating the pollution haven hypothesis in Ghana: an empirical investigation. Energy 124:706-719

Sun C, Zhang F, Xu M (2017) Investigation of pollution haven hypothesis for China: an ARDL approach with breakpoint unit root tests. J Cleaner Prodn. 161:153-164

Tang CF, Tan BW (2015) The impact of energy consumption, income and foreign direct investment on carbon dioxide emissions in Vietnam. Energy 79:447-454

Terzi H, Pata UK (2019) Is the pollution haven hypothesis (PHH) valid for Turkey? Panoeconomicus:1-18

United Nations Conference on Trade and Development (UNCTAD) (2019) Trade and Development Report 2019. United Nations, New York and Geneva

World Bank (2019) World development indicators. [Access: 05.09.2019]. https://databank.worldbank.org/indicator/NY.GDP. MKTP.KD.ZG/1ff4a498/Popular-Indicators\#

Zhang C, Zhou X (2016) Does foreign direct investment lead to lower $\mathrm{CO} 2$ emissions? Evidence from a regional analysis in China. Renewable and Sustainable Energy Reviews 58:943-951

Zivot E, Andrews DWK (1992) Further evidence on the Great Crash, the oil-price shock, and the unit-root hypothesis. J Bus Econ Stat 10: 251-270

Publisher's note Springer Nature remains neutral with regard to jurisdictional claims in published maps and institutional affiliations. 